\title{
[第38回総会シンポジウム】
}

\section{2. 放射線治療計画におけるコンピュータ処理とその精度について}

\author{
滋賀医科大学医学部附属病院放射線部
}

近 藤 康，雄・橋，本 恵 次

Key Words: Computerized dosimetry, Radiotherapy treatment planning.

\section{COMPUTERIZED DOSIMETRY ITS PRECISION IN RADIOTHERAPY TREATMENT PLANNING}

\author{
Yasuo Kondo, KeiJi Hashimoto
}

Department of Radiology, Shiga University of Medical Science Hospital

\section{Summary}

With Radplan 3D (ATC) we calculated the accuracy of computerization comparing the computerized data with the measured one.

We compared the pre set beam data with the measured data using $0.1 \mathrm{cc}$ chamber in various method of irradiation.

The result was that the total error was under $3 \%$.

The factor of the error are thought to be the followings

1. Error on taking in the beam data.

2. Error of approximation and error in writing with spark pen.

3. Error of effected SSD method in inhomogeneous correction.

\section{1. はじめに}

放射線治療用コンピュータは，主要施設において，治 療計画上，もはや不可欠な存在となっている。しかし， その治療技術への導入にあたって，演算処理過程で，八 一ドウェアおよびソフトウェア上の複雑な誤差要因が, トータルエラーと考えられる, 徒って, 放射線治療用コ ンピュータから得られる線量分布の計算結果と実测值が, 一致しているととが必要なととから，今回当院における 放射線治療用コンピュータについて，実測値との照合に 重点をおいて，精度を求め，検討を加えたので報告す る.

\section{2. 使用装置および器具}

\section{放射線治療装置}

NEC NELAC 1020 15 MV X線

放射線治療用コンピュータ

ATC RADPLAN 3D ISODOSE PLOTTER 線量計

IONEX (2500/3) $0.6 \mathrm{cc} 0.1 \mathrm{cc}$ chamber

CTスキャナ

$\mathrm{GE} \mathrm{CT/T} \mathrm{X-2}$

ファントム

水ファントム $(40 \mathrm{~cm} \times 40 \mathrm{~cm} \times 40 \mathrm{~cm})$

MixDp Alderson Rand phantom 


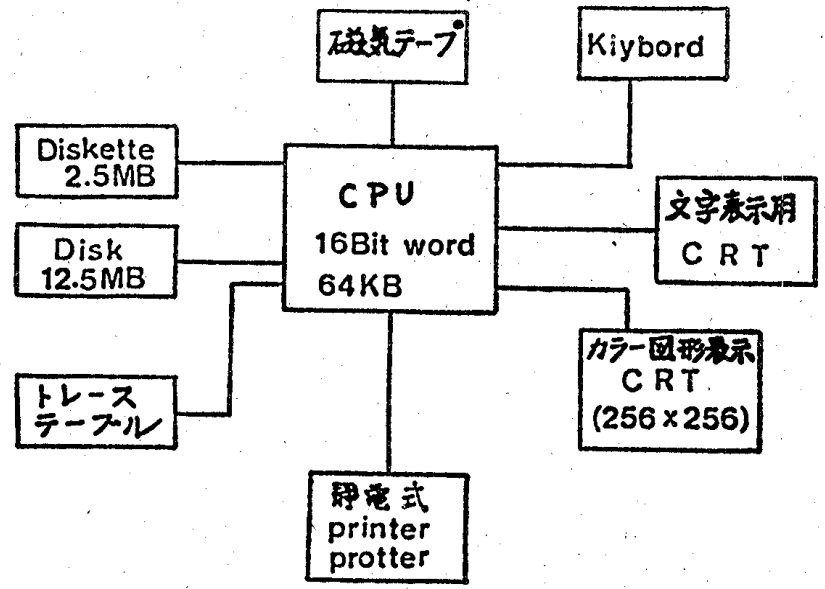

Fig. 1. The diagram shows construction of the Radplan 3D (ATC).

\section{3. ハードウェアの構成}

Fig. 1 は, RADPLAN 3D (ATC) のハードウェアの 構成である. CPU は 16 Bit ward, 64キロバイト；アク セスタイムは $400 \mathrm{nsec}$ 計算マトリクスは $54 \times 54$ ，ディ

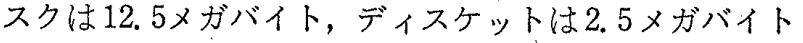
等である。

\section{4. ビームデータの取込み}

ビームデータの取込み方法は，コンピュータとアイソ ドーズプロッターをオンラインで接続し，照射野内の $D \max (3 \mathrm{~cm})$ の点に置くリファレンス線量計および，デ イテクター線量計は $0.1 \mathrm{cc}$ chamber で行った. $4 \times 4 \mathrm{~cm}$, $6 \times 6 \mathrm{~cm}$ の上うな偶数の照射野は, centralaxis data 之 profile data を取込み, $5 \times 5 \mathrm{~cm}, 7 \times 7 \mathrm{~cm}$ のような奇数 の照射野は, profile dataのみを取込むシステムになっ ている.なお, centralaxis data は depth interval を指 定して Dmax の点からデータを取込む，profile dataは， fan line, 47ポイントでその first depth は Dmax の深さ でそこから depth interval の 4 段目おきに, 5 cross spot のデータを取込むシステムになっている．てのようにし て，各照射野の単一ビームのデータを取込む．またウェ ッジビームの場合も，同様のビームデータの取込み方法 で行う. 振子照射, 回転照射等の運動照射については, 取込まれている単一ビームのデータをあとにして10度毎 の近似で処理される。な拈，計算時間については，単一。 ビームで数秒，回転照射では約 5 分程度である.

\section{5. ビームデータ取込み手技による差異}

実験当初，コンピュータ処理のテスト段階で, 線量分 布に䇥みがあることに着目し，まずその誤差要因の検討
を行った，誤差要因として，ビーム自体の平坦度と安定 性, 駆動装置付水ファントムの駆動装置の精度々その水 準の取り方等が考えられた。そこでまず，駆動装置の精

Table 1. Comparison of the beam profile after adjustment (A) with one before adjustment (B).

[A] AFTER ADJUSTMENT

\begin{tabular}{r|c|c|c|c|c}
\hline $\begin{array}{r}\text { Cross } \\
\text { spot }\end{array}$ & 1 & 2 & 3 & 4 & 5 \\
\hline Fan line & 1 & & & \\
\hline 1 & 0.079 & 0.082 & 0.097 & 0.111 & 0.120 \\
2 & 0.092 & 0.098 & 0.113 & 0.127 & 0.138 \\
3 & 0.116 & 0.123 & 0.138 & 0.152 & 0.163 \\
4 & 0.167 & 0.167 & 0.186 & 0.197 & 0.210 \\
5 & 0.312 & 0.294 & 0.301 & 0.326 & 0.331 \\
$\vdots$ & $\vdots$ & $\vdots$ & $\vdots$ & $\vdots$ & $\vdots$ \\
$\vdots$ & $\vdots$ & $\vdots$ & $\vdots$ & $\vdots$ & $\vdots$ \\
22 & 0.998 & 1.003 & 0.995 & 1.004 & 0.992 \\
23 & 1.007 & 0.998 & 0.996 & 1.000 & 0.995 \\
24 & 0.999 & 1.003 & 0.994 & 0.998 & 0.990 \\
25 & 1.000 & 0.999 & 0.995 & 0.998 & 0.990 \\
26 & 0.997 & 0.998 & 0.995 & 0.998 & 0.994 \\
$\vdots$ & $\vdots$ & $\vdots$ & $\vdots$ & $\vdots$ & $\vdots$ \\
$\vdots$ & $\vdots$ & $\vdots$ & $\vdots$ & $\vdots$ & $\vdots$ \\
43 & 0.286 & 0.276 & 0.281 & 0.298 & 0.291 \\
44 & 0.157 & 0.163 & 0.179 & 0.187 & 0.195 \\
45 & 0.112 & 0.120 & 0.135 & 0.147 & 0.155 \\
46 & 0.091 & 0.097 & 0.110 & 0.124 & 0.134 \\
47 & 0.078 & 0.081 & 0.097 & 0.109 & 0.119 \\
\hline & & & & & \\
\hline
\end{tabular}

[B] BEFORE ADJUSTMENT

\begin{tabular}{c|c|c|c|c|c}
\hline $\begin{array}{r}\text { Cross } \\
\text { spot }\end{array}$ & 1 & 2 & 3 & 4 & 5 \\
\hline $\begin{array}{c}\text { Fan line } \\
1\end{array}$ & 0.217 & 0.208 & 0.207 & 0.213 & 0.214 \\
2 & 0.479 & 0.430 & 0.406 & 0.392 & 0.385 \\
3 & 0.780 & 0.735 & 0.699 & 0.683 & 0.685 \\
4 & 0.903 & 0.862 & 0.854 & 0.843 & 0.842 \\
5 & 0.949 & 0.918 & 0.907 & 0.902 & 0.895 \\
$\vdots$ & $\vdots$ & $\vdots$ & $\vdots$ & $\vdots$ & $\vdots$ \\
$\vdots$ & $\vdots$ & $\vdots$ & $\vdots$ & $\vdots$ & $\vdots$ \\
22 & 0.999 & 0.999 & 0.999 & 1.000 & 0.998 \\
23 & 1.000 & 0.999 & 1.001 & 1.001 & 1.001 \\
24 & 1.001 & 0.998 & 1.000 & 0.999 & 1.002 \\
25 & 1.002 & 1.001 & 1.002 & 1.001 & 0.999 \\
26 & 1.004 & 1.001 & 1.002 & 1.002 & 1.002 \\
$\vdots$ & $\vdots$ & $\vdots$ & $\vdots$ & $\vdots$ & $\vdots$ \\
$\vdots$ & $\vdots$ & $\vdots$ & $\vdots$ & $\vdots$ & $\vdots$ \\
43 & 0.078 & 0.091 & 0.105 & 0.118 & 0.125 \\
44 & 0.066 & 0.074 & 0.080 & 0.100 & 0.108 \\
45 & 0.059 & 0.065 & 0.078 & 0.089 & 0.097 \\
46 & 0.053 & 0.058 & 0.070 & 0.081 & 0.088 \\
47 & 0.048 & 0.052 & 0.064 & 0.073 & 0.079 \\
\hline
\end{tabular}


度，水準性を充分に確保した上で再度ビームデータの取 込みを行い当初得たビームデータとの比較を行った。

Table 1 は，両者に取込まれた，profile data を比べ たものだが，(A)では，fan line 1 付近と47付近でよく一 致しているが, (B)では, crossspotの1段から 5 段のいず れにおいても，fon line 1 付近の方が47付近より，高く データが取込まれている.なお照射野は $10 \times 10 \mathrm{~cm}$.

Fig. 2 は, 両者の照射野 $10 \times 10 \mathrm{~cm}$ の時の等線量曲線 を示したすので(A)では平坦度のよい等線量曲線が得られ ているが, (B)では等線量曲線に歪みが観察される。

Fig. 3 の左側のグラフは, Table 1 のデータの内,
AFTER ADJUSTMENT

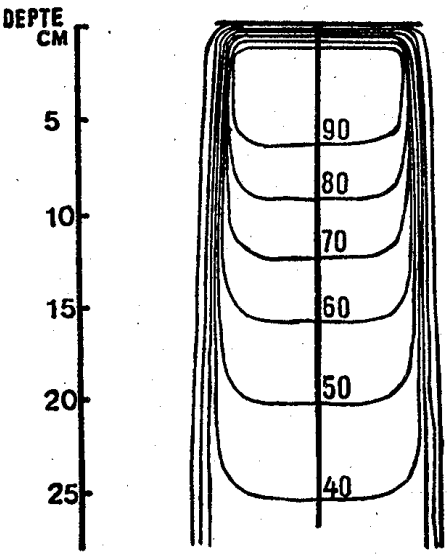

(A)
BEFORE ADJUSTMENT

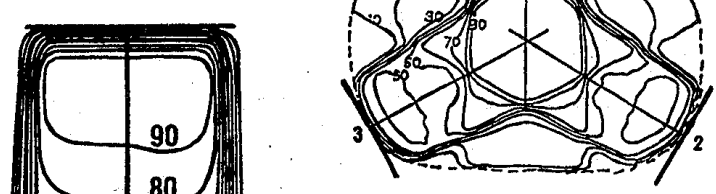

(A) cross spot 1 段つまり Dmax の点の深さにおける profile data をグラフ化したもので水ファントムの水準性の保 たれていない方に非対称性がみられた。これは微少傾斜 するととにより，水面と水ファントムの中心軸が直交し ていないために生じたすのと考えられる。

とれらをむう少し検討してみるとFig. 4 は，それぞれ 照射野 $10 \times 10 \mathrm{~cm} 0^{\circ} ， 120^{\circ} ， 240^{\circ}$ の三門照射の線量分布 で（A)に比べて(B)の方が特に70\%以上の所で歪みが顕著 に生じている。Fig. 5 は，それぞれ照射野 $10 \times 10 \mathrm{~cm}$, 振子角 $120^{\circ}$ の振子照射の線量分布で(A)では対称的であ

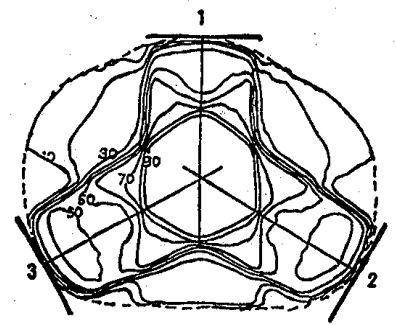

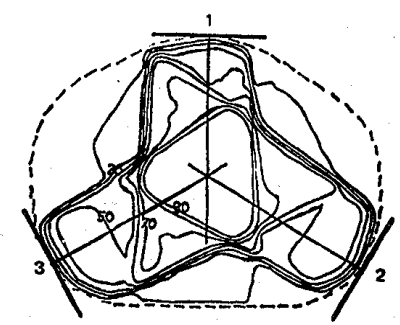

(B)
Fig. 4. Comparison of the dose distribution at the horizontal level (A) with one a little inclination (B). The beam is three beams form $\left(0^{\circ}, 120^{\circ}, 240^{\circ}\right)$,

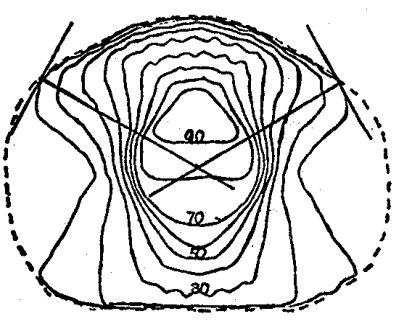

[A]

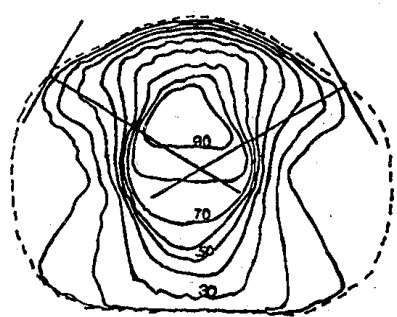

(B)
Fig. 5. Comparison of the dose distribution at the horizontal level (A) with one a little inclination (B). The beam is arc irradiation $120^{\circ}$.

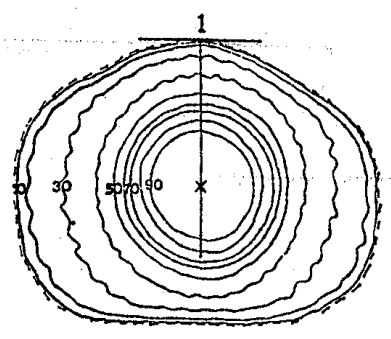

$[A]$

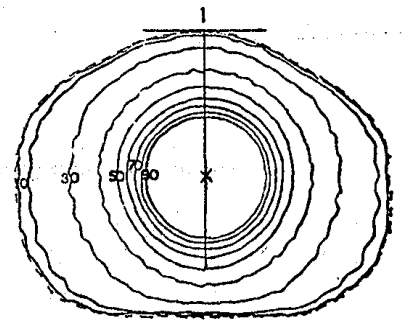

(B]
Fig. 3. Radiation profile at a depth of Dmax of $10 \mathrm{~cm} \times 10 \mathrm{~cm}$. Solid lines show the data at the horizontal level, broken lines show the data with a little inclination.
Fig. 6. Comparison of the dose distribution at the horizontal level (A) with one a little inclination ( $B)$. The beam is rotational irradiation. 


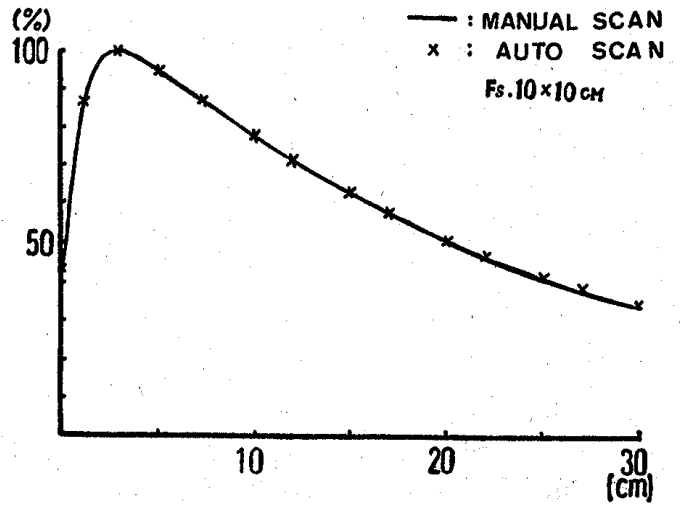

Fig. 7. Difference of the depth dose curve between the mannual scanning and the auto scanning.

るのに対し(B)では左へ歪んだ分布がみられる. Fig. 6 は， それぞれ照射野 $10 \times 10 \mathrm{~cm}$ の回転照射の線量分布で(A) に比べて(B)の方に，90\%域が広くなっているのが見られ る.

Fig. 7 は, 駆動装置付水ファントムの深さに関する精 度について，自動スキャンニング，手動スキャンニング をし，深部率曲線のデータを収集し比べたものだが，ほ ぼ一致した結果が得られたが，自動スキャンニングする 場合，駆動装置の立ち上り部分の動作を正確にさせるこ とにより更に改善の余地がある，以上のととから，駆動 装置の精度, 水ファントムの水準性を充分確保すること で正確なビームデータの取込みがなされたと考えられ る.

\section{6. 実測値とコンピュータ処理值の比較}

以上の経験をむとにして，正確に取込ま机たビームデ ータを用い治療用コンピュータの精度について実測值と コンピュータ処理值の比較を様々な照射法で確めた。

Fig. 8 は, 基本となる単一ビームの照射野 $4 \times 4 \mathrm{~cm}$, $10 \times 10 \mathrm{~cm}, 20 \times 20 \mathrm{~cm}$ の深部量百分率の実測值とコンピ ュータ処理值の比較をしたすので水ファントムを用い $0.1 \mathrm{cc}$ chamber て測定した，各照射野共，両者はよく 一致している.

Fig. 9 は, 単一ビームの照射野 $4 \times 4 \mathrm{~cm}, 10 \times 10 \mathrm{~cm}$, $20 \times 20 \mathrm{~cm}$ の等線量曲線の実測值とコンピュー夕処理值 の比較をしたもので水ファントムを用い $0.1 \mathrm{cc} \mathrm{cham-}$ ber で測定した，各照射野共ほぼ一致した傾向が見られ るあのの, 照射野が, 大きくなるにつれて, 歪みのある 個所が見られるが，乙れは，コンピュータの近似の間隔 が広くなるためと考えられる。

Fig. 10 は, 照射野 $10 \times 10 \mathrm{~cm} の 0^{\circ} ， 120^{\circ} ， 240^{\circ}$ の三

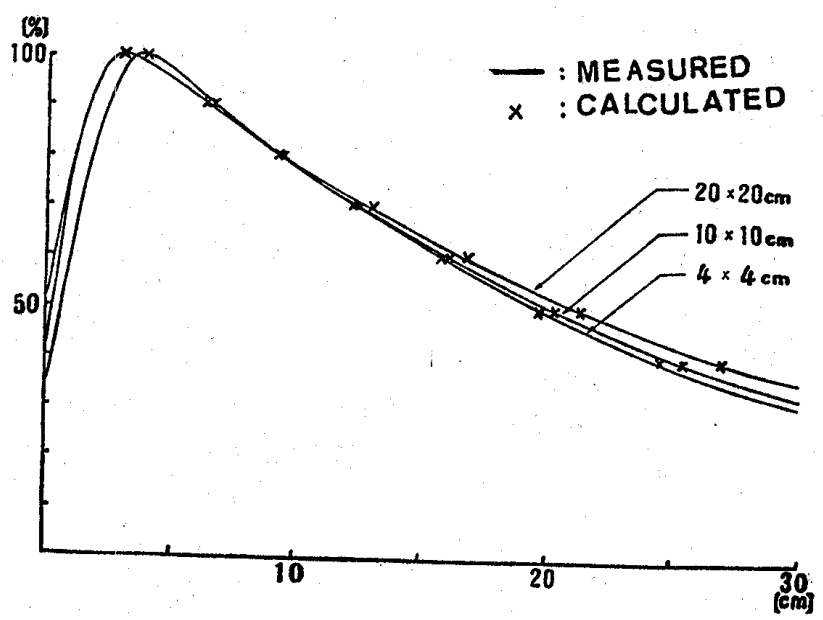

Fig. 8. Difference between the depth dose curve with the measured data and that with the calculated data in various field sizes.

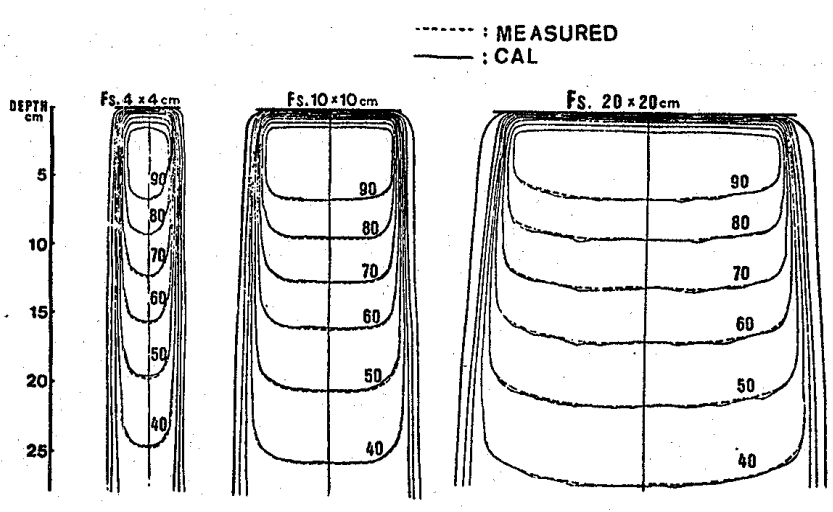

Fig. 9. Comparison of the measured curves with tha calculated ones.

閔照射について実測值とコンピュータ処理值の比較をし たむので，MixDp ファントムを用い，アイソセンター を原点之して，X方向， $Z$ 方向，斜45度 $A$ 方向に各々 2 $\mathrm{cm}$ の間隔で実測は $0.1 \mathrm{cc}$ chamberを用いた．各方向 共, 最大值附近でよく一致しているが周辺部分に高々 1 〜 2\%程の差がみられる点がある.

次に回転照射について，照射野を変化させ実測值とコ ンピュータ処理值の比較を行った. MixDp ファントム を用い，アイソセンターを原点として，X方向， $Z$ 方向， 斜 45 度 $\mathrm{A}$ 方向に备々 $2 \mathrm{~cm}$ の間隔で奏測は $0.1 \mathrm{cc}$ chamberを用いた。

Fig. 11 は, 照射野 $5 \times 5 \mathrm{~cm}$ の回転照射における 3 方 向の実測值とコンピュータ処理値の比較をしたもので， 中心率においてよく一致しているが，周辺部において 1 〜2\%程の差がみられる点がある。

Fig. 12 は, 照射野 $10 \times 10 \mathrm{~cm}$ の回転照射に求ける 3 方向の実測值とコンピュータ処理值の比較をしたもので 

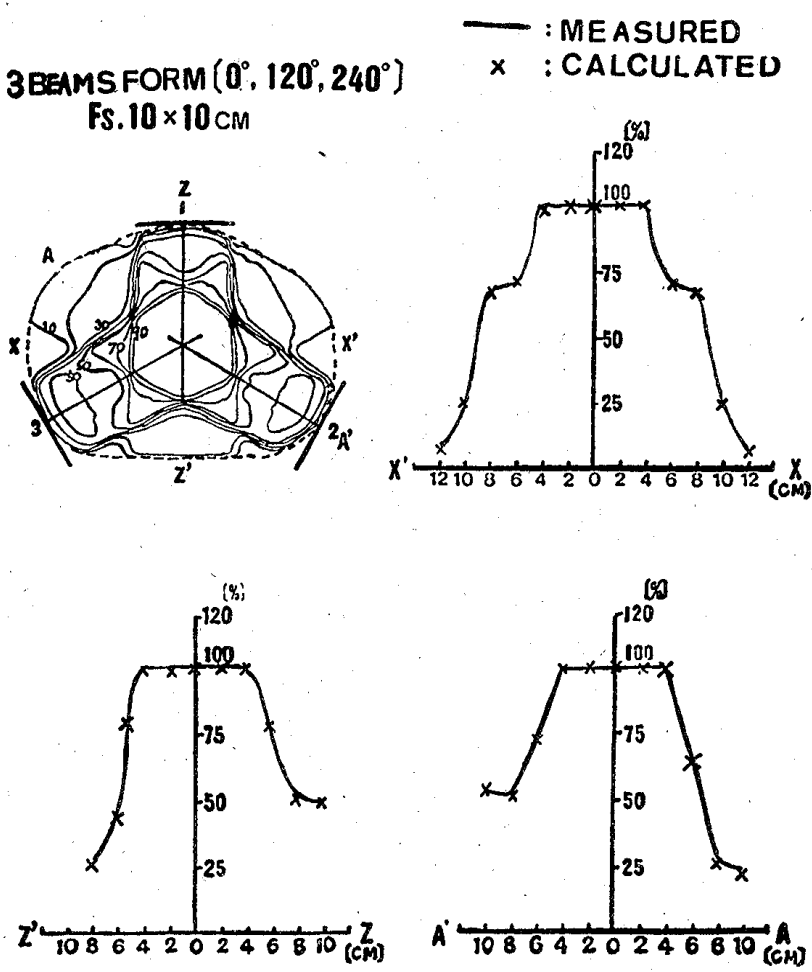

Fig. 10. Comparison of the measured data with the calculated data in case of three beams form $\left(0^{\circ}, 120^{\circ}, 240^{\circ}\right)$.
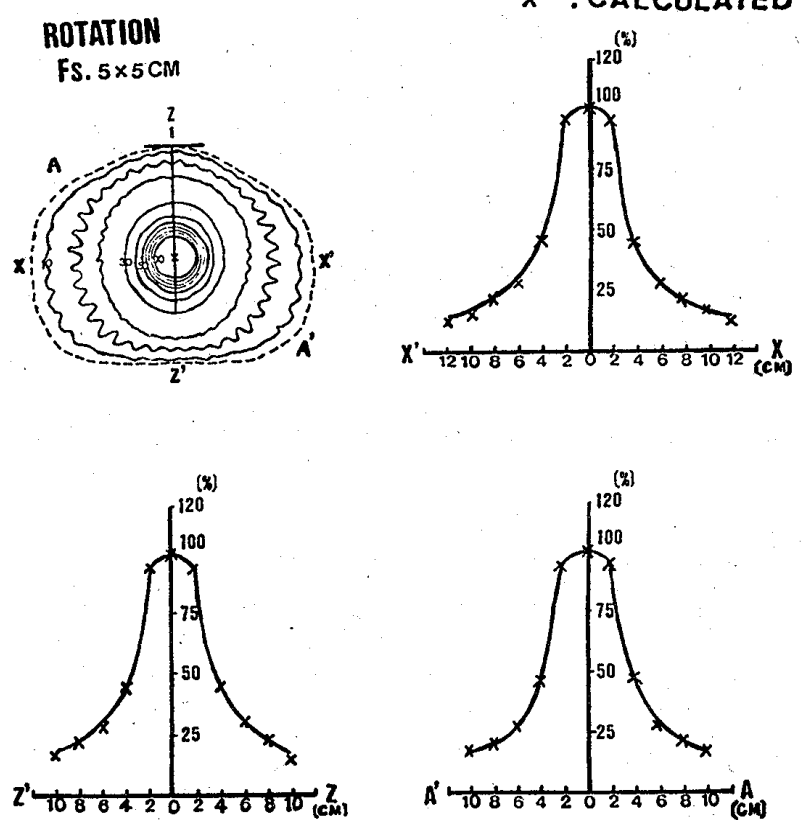

Fig. 11. Comparison of the measured data with the calculated data in case of rotation method with field size of $5 \mathrm{~cm} \times 5 \mathrm{~cm}$.

この場合も周边部において 1 ～2\%程の考がみられる点 がある。

Fig. 13 は，照射野 $15 \times 15 \mathrm{~cm}$ の回転照射における，
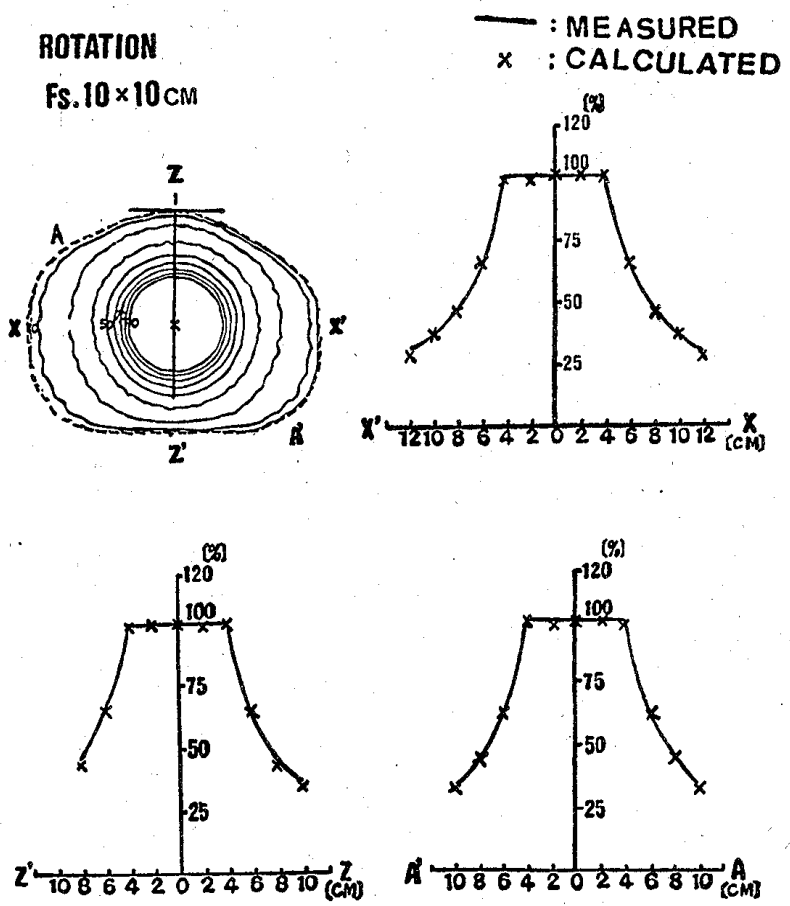

Fig. 12. Comparison of the measured data with the calculated data in case of rotation method with field size of $10 \mathrm{~cm} \times 10 \mathrm{~cm}$.

ROTATION

Fs. $15 \times 15 \mathrm{~cm}$
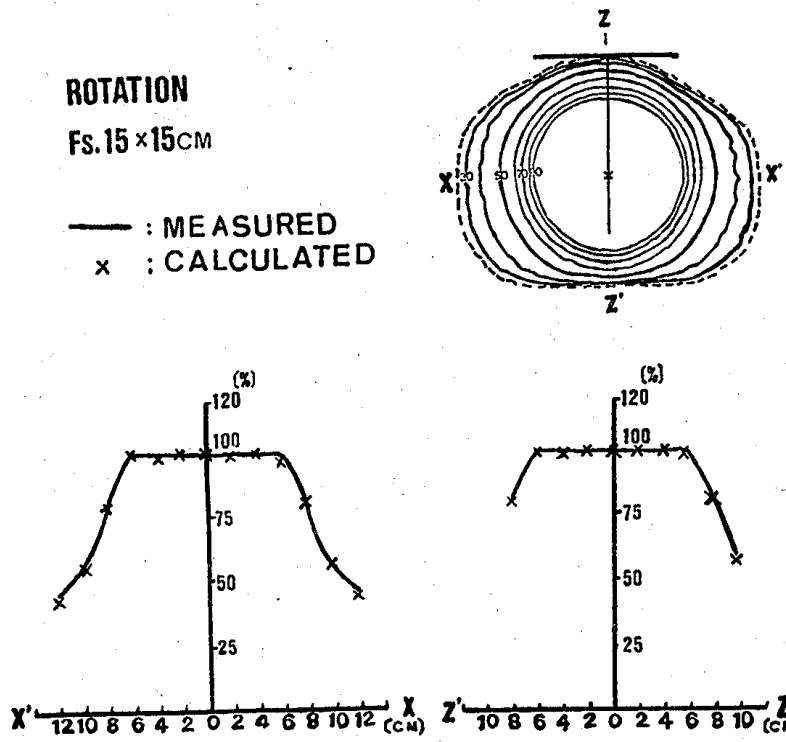

Fig. 13. Comparison of the measured data with the calculated data in case of rotation method with field size of $15 \mathrm{~cm} \times 15 \mathrm{~cm}$.

$\mathrm{X}$ 方向， $\mathrm{Z}$ 方向の 2 方向について実測值とコンピュータ 処理值の比較をしたものでしの場合す照射野 $5 \times 5 \mathrm{~cm}$, $10 \times 10 \mathrm{~cm}$ 同様の結果を示した. 回転照射に执いて, 照 射野を変化させても, 周辺部で 1 ～2\%の差が見られる 以外は，実測值とコンピュー夕处理值に淤いてほぼ一致 した結果が得られた. 周辺部での差は, コンピュータ処 
理において10度毎の近似をおこなうために生じる差と考 えられる.

次に振子照射について，振子角を変化させ実測值とコ ンピュータ処理值の比較を行った。照射野 $10 \times 10 \mathrm{~cm}$ で, MixDp ファントムを用い, アイソセンターを原点とし て, X方向， $Z$ 方向；斜 45 度 $A$ 方向に $2 \mathrm{~cm}$ の間隔で， 実測は $0.1 \mathrm{cc}$ chamber を用いた。

Fig. 14 は, 振子角 120 度で 3 方向の実測値とコンピュ ー夕処理値の比較をしたもので 3 方向共, 周辺部で 1 $2 \%$ 差がみられる点がある.

Fig. 15 は，振子角150度でX方向， $Z$ 方向， 2 方向の 実測值とコンピュータ処理值を比較したもので， 2 方向 共, 周辺部で $1 \sim 2 \%$ 差が見られる.

Fig. 16 は，振子角 180 度で $\mathrm{X}$ 方向， $Z$ 方向， 2 方向の 実測值とコンピュータ処理值を比較したもので, 振子角 120度，150度同様の結果を示した. 振子照射において, 振子角を変化させても周辺部での $1 \sim 2 \%$ 差以外は, 実測值とコンピュータ処理値は，ほぼ一致した結果が得 られた。 また，周辺部での差は，回転照射同様に振子照 射の場合も10度每の近似をするコンピュータ処理に原因 があると考えられる.

以上のととからコンピュータ処理における運動照射の 10度毎の近似は，周辺部で $1 \sim 2 \%$ 差があるあのの治 療領域では，ほぼ一致している結果が得られた。

次にウェッジ照射について，ウェッジ角を変化させ，
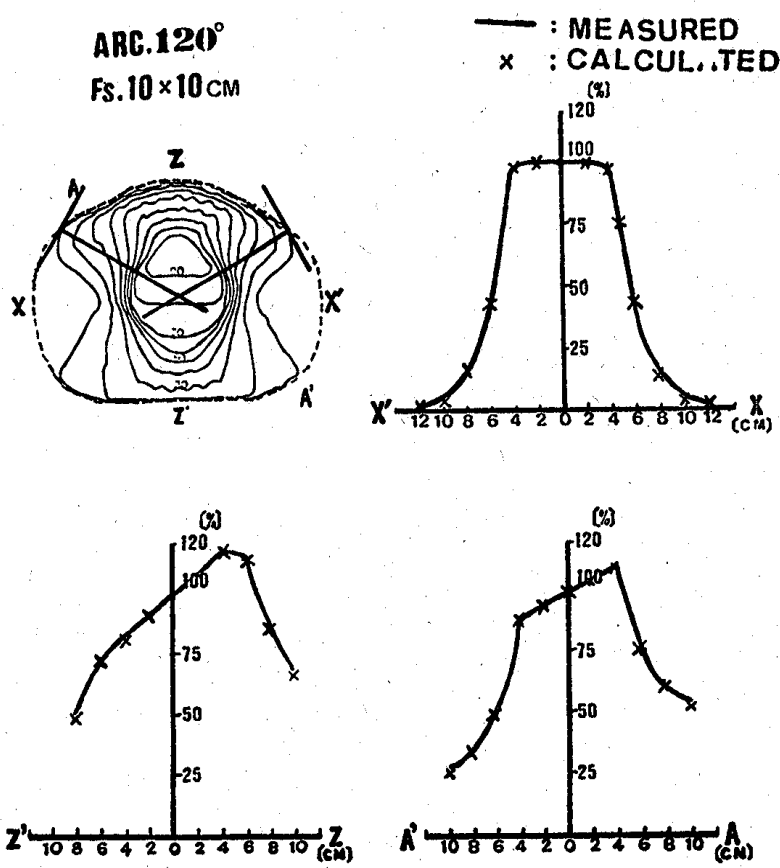

Fig. 14. Comparison of the measured data with the calculated data in case of arc irradiation $120^{\circ}$,
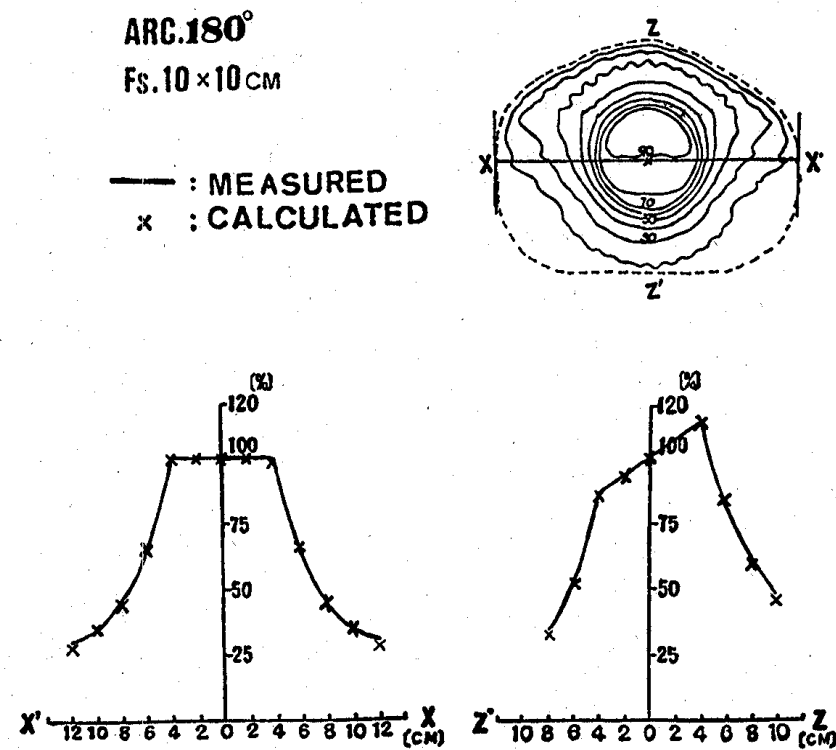

Fig. 15. Comparison of the measured data with the calculated data in case of arc irradiation $150^{\circ}$.
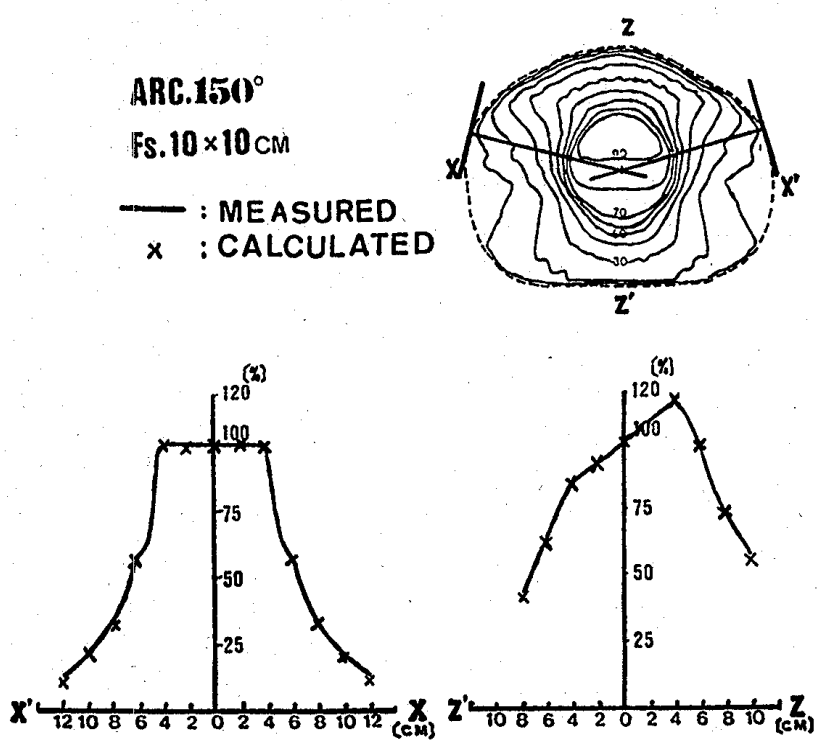

Fig. 16. Comparison of the measured data with the calculated data in case of arc irradiation $180^{\circ}$.

実測值とコンピュータ処理値の比較を行った．照射野 10 $\times 10 \mathrm{~cm}$ で水ファントム中 $10 \mathrm{~cm}$ 深さをX方向にスキャ ンした。な揍測は $0.1 \mathrm{cc}$ chamber を用いた。 結果を Fig. 17 亿示した. 30度ウェッジ，45度ウェッジは，ほ ぼ一致した結果を示したが，60度ウェッジでは， 1〜2 \%の差が見られた．次に実際の直交二閒照射について45 度ウェッジ，照射野 $10 \times 10 \mathrm{~cm}$ で MixDp ファントムを 用い実測值とコンピュータ処理値について比較を行い, 実測は $0.1 \mathrm{cc}$ chamber で測定した. その結果を Fig. 18 

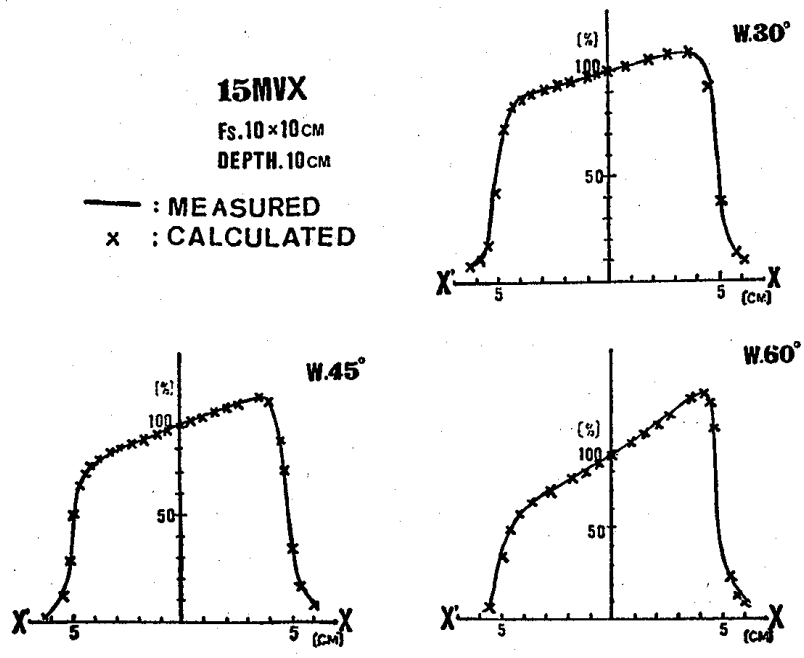

Fig. 17. Difference between the isodose curve at the depth of $10 \mathrm{~cm}$ with the measured data and that with the calculated data in various wedge angle.
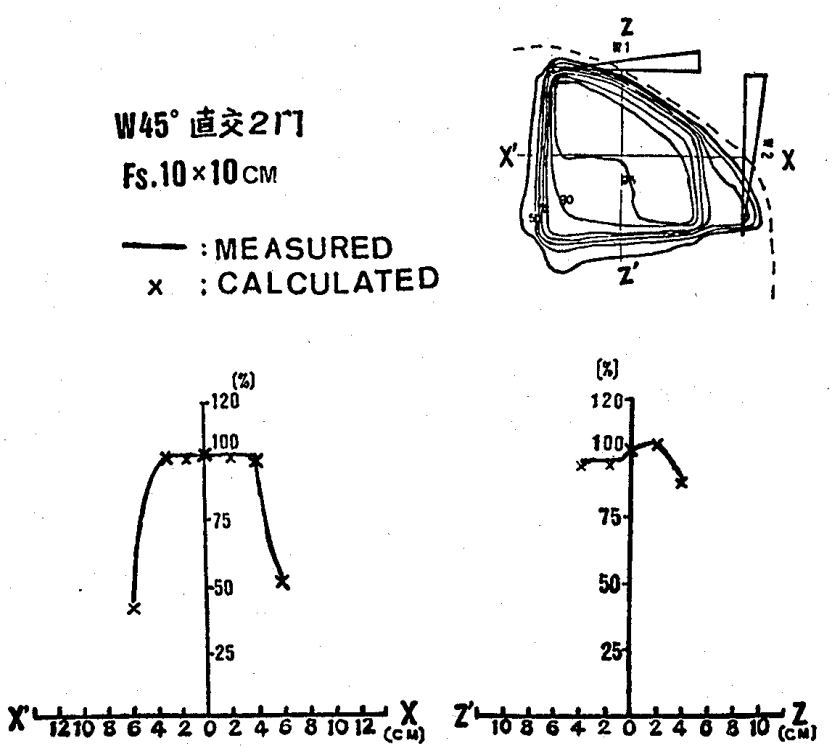

Fig. 18. Comparison of the measured data with the calculated data in case of combining two wedge beam $\left(45^{\circ}\right)$.

に示す. Z 方向は, ファントムの辺縁につき, 測定点を 多くとれなかったが，X方向， $Z$ 方向での差は， $2 \sim 3$ \%であった.

\section{7. 異質密度補正 (肺補正)の精度について}

特に肺補正について検討を行った．異質密度補正は， $\mathrm{GE}$ の CT スキャナから得られた CT 值と相対電子密度 の関係が, コンピュータに入力してあって, ピクセル毎 の補正を行っている.

Table 2 上段は，前一閔照射の場合でファントムの胡
Table 2. The upper shows difference between the caluculated data and the measured one.

The lower shows difference of the correction factor between the three method.

$\left(\begin{array}{l}15 M V X \\ \text { Fs.10 } \times 10 \mathrm{~cm}\end{array}\right)$
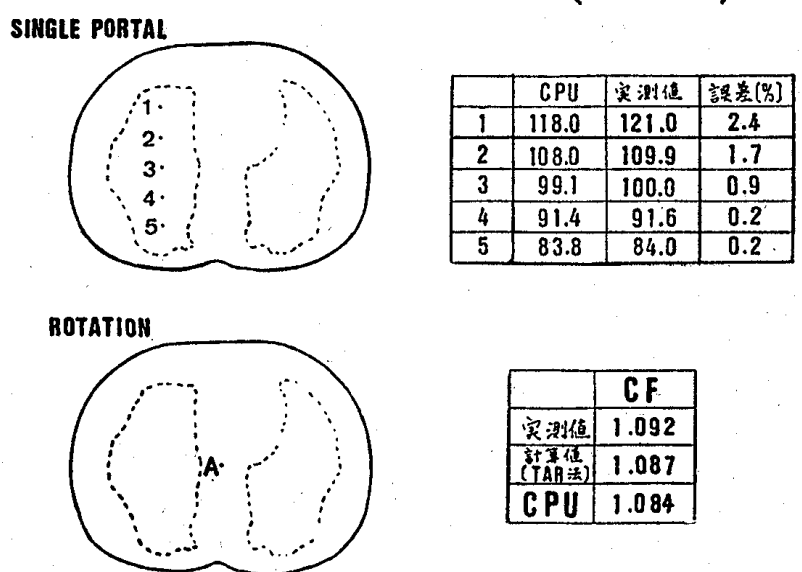

野に $3 \mathrm{~cm}$ の間隔で 1 〜 5 な゙の点を测定点とし, それ ぞれの線量值を定測值とコンピュータ処理值で比較し た。なお実測は $0.1 \mathrm{cc}$ chamber で測定した. 結果, 测 定点 $3 \sim 5$ は, $1 \%$ 末満とよく一致しているが, 測定点 1 および 2 は，1\%以上の差が生じている．てれは等線 量曲線の幅の狭い所では, スパークペンの少々のずれに より線量值が変動しやすく, 差の要因となりやすい. ま た，コンピュータは，実効 SSD 法による補正を行うこ とあその要因の一つと考えられる.

次に下段は，回転照射の場合で回転中心 A の correction factor (CF) について, 実測值, ICRU24にもとづ くTAR 法での手計算值, コンピュータ姏理值の 3 種で 比較した．実測は $0.1 \mathrm{cc}$ chamber で行った。回転照射 の場合，それぞれの差は，1\%末満とよく一致している ととが確認できた. 以上が今回われわれが行った実験で ある・

\section{8. ま と}

放射線治療計画専用 そニコンピュータによるデータ処 理, 計算過程を通じて生じる様々な䛊差要因について, 多角的に検討を加えた結果, 全体を通じて, 実測值とコ ンピュータ処理值の誤差は, 何れす $3 \%$ 末藏となってお り，その精度としては，満足する值であった。しかし， われわれが, 当初経験したように, 安易に取込まれたビ ームデータで日常治療計画を行うには，当然それなりの 䛊差が，あたらされるのではないかと思う.よってビー 
ムデータの取込みいかんによっては，治療用コンピュー タの精度を大きく左右されると考える.またりフトウェ ア上での誤差要因としては，近似計算好理の精度，スパ ークペン処理の精度，異質密度補正において実効 SSD 法による補正等が考えられる. 今後の問題点として, 計 算のアルゴリズム, ソフトウェア等について, メーカ側 から公表されなかったため，詳しく検討できなかったが， 今後义一力側の協力を得て，検討していきたいと思う.

稿を終えるに当り，シンポジウムの機会を与えて頂い た第38回日本放射線技術学会総会の役員の皆様に深く感 謝いたします。また，御指導，御協力をいただきました 滋賀医大病院放射線部雄川技師長はじめ，技師室の技師 諸见に感謝の意を表します。

\section{文 献}

1) J. Milan, R. E. Bently: The storage and manipulation of radiation dose data in a small digital computer, Brit. J. Radiol., 47, 115-121, (1974).

2) Determination of absorbed dose in a patient irradiation by beams of $\mathrm{X}$ or gamma rays in radiotherapy procedures. ICRU Report, 24, (1976).

3) Sontag, M. R., Cunningham, Jh.: Corrections to absorbed dose calculations for tissue inhomogeneities, Medical Physics, 4, 431-436, (1977).

4) Sontag, M. R., Cunningham, Jh.: The equivalant tissue-air ratio method for making absored tomography for inhomogeneity corrections in photon beam dose calculation, Radiology, 124, 143-149, (1978).

5) E. C. Mceullough, A. M. Krueger: Performance evaluation of computerized treatment planning systems for radiotheraphy: external photon beams. Radiation Oncology. Biol. phys, 6, (1980). 